\title{
The potential for large scale savings from insulating residential buildings in the EU
}

Originally published as:

Stefan Lechtenböhmer, Andreas Schüring (2009):

The potential for large scale savings from insulating residential buildings in the EU In: Energy efficiency, 4, 2, 257-270

DOI: $10.1007 / \mathrm{s} 12053-010-9090-6$ 
Stefan Lechtenböhmer ${ }^{a,{ }^{*}}$, Andreas Schüring ${ }^{\mathrm{b}}$

\section{The potential for large scale savings from insulating residential buildings in the EU}

a Wuppertal Institute for Climate, Environment and Energy GmbH, Germany

b Federal Ministry of Transport, Building and Urban Development, Berlin, Germany

* Corresponding author: Stefan Lechtenböhmer, Wuppertal Institute for Climate, Environment and Energy GmbH, Döppersberg 19, 42103 Wuppertal, Germany

E-mail: stefan.lechtenboehmer@wupperinst.org

Phone: +49-202-2492216

Fax: $+49-202-2492-198$ 


\section{The potential for large scale savings from insulating residential buildings in the EU}

\section{Keywords.}

energy efficiency, energy saving potentials in buildings, residential building sector, EU27, policies and measures for energy efficiency

\section{Abstract}

Energy used in buildings is responsible for more than $40 \%$ of energy consumption and GHG emissions of the EU and their share in cost efficient GHG mitigation potentials is estimated to be even higher. In spite of its huge savings potential up to $80 \%$ achievements are very slow in the building sector and much stronger political action seems to be needed. One important step in this direction has been the recast of the Energy Performance of Buildings Directive (EPBD) in autumn 2009. However, strong national implementation including powerful packages of flanking measures seem to be crucial to really make significant progress in this important field.

In order to directly improve political action we provide a differentiated country by country bottom up simulation of residential buildings for the whole EU, Norway, Iceland, Croatia and Liechtenstein. The analysis provides a database of the building stock by construction periods, building types, as well as typical building sizes. It includes a simulation of the thermal quality and costs of the components of the building shell for new buildings as well as the refurbishment of the existing building stock.

Based on this differentiated analysis we show in detail what would be needed to accelerate energy savings in the building sector and provide a more precise estimate of the potentials to be targeted by particular policies. We demonstrate e.g. that the potential of building codes set via the European Performance Building Directive (EPBD) would be located mainly in those countries that already have quite stringent codes in place. We show as well the high relevance of accelerating refurbishments and re-investment cycles of buildings. By providing a clear estimate of the full costs related to such a strategy we highlight a major obstacle to accelerated energy-efficient building renovation and construction.

\section{Introduction}

Energy efficiency measures in the building sector provide enormous potentials to reduce $\mathrm{CO}_{2}$ emissions in Europe. Energy used in buildings is responsible for more than $40 \%$ of energy consumption and GHG emissions of the EU. The sectors share of the cost efficient GHG mitigation potentials seems to be even higher. This high amount of emissions could be reduced up to $80 \%$ by comparably simple measures, e.g. better insulation of the different components of the existing building stock, refurbished dwellings, as well as for new buildings ${ }^{1}$. One important step to instrument these has been the recast of the Energy Performance of Buildings Directive (EPBD) in autumn 2009. However, strong national implementation including powerful packages of flanking measures seem to be crucial to really make significant progress in this important field.

This paper provides a description and results of a detailed bottom up model of the current and future residential building stock in the EU which comprises of the following elements:

- Comprehensive country by country database and model of the EU residential building stock, by construction period and building type, the average living area and building sizes;

- Static building simulation that simulates the thermal quality (insulation of all building components and the resulting useful energy demand of the building, according to the specific geometry of the building);

- Detailed representation of the energy quality and the costs of a range of technologies for refurbished and new buildings.

Based on this model different scenarios on the potentials for energy efficiency coupled with the refurbishment of existing and improvement of new buildings and are presented and interpreted with regards to specific policy options.

It has to be acknowledged that the model applied and presented here comprises a significant simplification of the complex characteristics of the dozens of millions EU residential buildings. However it is to our knowledge still the

\footnotetext{
${ }^{1}$ EURIMA, ECOFYS 2005a,b; Lechtenböhmer et al. 2005
} 
most detailed EU-wide and country specific building stock model ${ }^{2}$. In spite of the significant uncertainties resulting from the lack of precise statistical information about the characteristics of the EU building stock - which are larger, when benchmarking countries vs. each other and smaller when comparing the overall results for the EU or for regions in the EU - our simulations still reveal important results for policy makers on the EU and MS level and provides rough quantifications of the potentials, relevance and costs of different strategies toward an improvement of the building shell qualities of residential buildings in the EU.

\section{The building stock model}

In order to calculate energy saving potentials a country by country database is necessary to define the current national residential building stocks. Therefore, the construction periods and building types, the average living area of each country has to be taken into account as well as typical building sizes are defined.

Differentiated data about the age and distribution of the European building stock for each country is quite rare but necessary in order to define its physical characteristics and the breakdown of the building types and to evaluate the saving potentials. However, the building quality depends also on the extent of refurbishment and the point in time at which it has been or will be carried out. First insights are provided by Housing statistics in the European Union 2004 and its revision from $2005 / 2006^{3}$ and several other reports like EURIMA report ${ }^{4}$ which analysed the European building stock. All in all, the data about construction periods between each country vary and therefore some inaccuracies may exist. Table 1 gives an overview about the building stock in the two main construction periods of the existing building stock and the share of single and multi family buildings.

Due to regional differences in each country it can be observed that some countries have almost the same amount of single and multi family buildings, e.g. Portugal, Spain, Austria, Romania, Slovakia, Bulgaria, Germany and a projected equal share in Croatia. In the Netherlands, Belgium, Luxemburg, Ireland, Norway and United Kingdom the amount of single family buildings is much higher, meanwhile the amount of multi family buildings in almost every new EU Member State is twice high or much higher than single family buildings. This is to be observed especially in the Baltic countries and in Poland.

Table 1: $\quad$ Residential building stock 2004 overview by construction period (in \% of total number of dwellings)

\begin{tabular}{|c|c|c|c|c|c|c|c|c|c|}
\hline & \multicolumn{2}{|c|}{ built } & \multicolumn{2}{|c|}{ share of } & & \multicolumn{2}{|c|}{ built } & \multicolumn{2}{|c|}{ share of } \\
\hline & $\begin{array}{c}\text { before } \\
1975\end{array}$ & $\begin{array}{c}1976- \\
2004 \\
\end{array}$ & $\begin{array}{l}\text { Single } \\
\text { family }\end{array}$ & $\begin{array}{c}\text { Multi } \\
\text { family }\end{array}$ & & $\begin{array}{c}\text { before } \\
1975\end{array}$ & $\begin{array}{l}1976- \\
2004\end{array}$ & $\begin{array}{l}\text { Single } \\
\text { family }\end{array}$ & $\begin{array}{l}\text { Multi } \\
\text { family }\end{array}$ \\
\hline Austria & 48 & 52 & 56 & 44 & Italy & 71 & 29 & 29 & 71 \\
\hline Belgium & 79 & 21 & 70 & 30 & Liechtenstein & 43 & 57 & 56 & 44 \\
\hline Bulgaria & 86 & 14 & 56 & 44 & Lithuania & 64 & 36 & 25 & 75 \\
\hline Croatia & 47 & 53 & 56 & 44 & Luxemburg & 49 & 51 & 70 & 30 \\
\hline Cyprus & 38 & 62 & 43 & 57 & Latvia & 64 & 36 & 25 & 75 \\
\hline Czech Republic & 33 & 67 & 42 & 58 & Malta & 63 & 37 & 82 & 18 \\
\hline Germany & 81 & 19 & 47 & 53 & Netherlands & 57 & 43 & 70 & 30 \\
\hline Denmark & 72 & 28 & 59 & 41 & Norway & 65 & 35 & 76 & 24 \\
\hline Estonia & 60 & 40 & 25 & 75 & Poland & 47 & 53 & 33 & 67 \\
\hline Greece & 55 & 45 & 43 & 57 & Portugal & 43 & 57 & 50 & 50 \\
\hline Spain & 62 & 38 & 50 & 50 & Romania & 82 & 18 & 56 & 44 \\
\hline Finland & 53 & 47 & 54 & 46 & Sweden & 71 & 29 & 43 & 57 \\
\hline France & 61 & 39 & 57 & 43 & Slovenia & 69 & 31 & 36 & 64 \\
\hline Hungary & 46 & 54 & 61 & 39 & Slovakia & 31 & 69 & 49 & 51 \\
\hline Ireland & 46 & 54 & 92 & 8 & United Kingdom & 71 & 29 & 81 & 19 \\
\hline Iceland & 56 & 44 & 76 & 24 & & & & & \\
\hline
\end{tabular}

Source: Own calculations based on Boverket, MMR (2005); MIIR, FIHF (2007) and EURIMA, Ecofys (2005a)

\footnotetext{
${ }^{2}$ There are more detailled models e.g. for Germany, which represent the nations residential buildings by about 20 representative buildings, based on building statistics and emprical results on their energetic quality. However, even for these modells data availability is a core problem.

${ }^{3}$ Boverket, MMR 2005; MIIR, FIHF 2007

4 (EURIMA 2005)
} 
Based on PRIMES, Odyssee and national projections, it is projected that the total numbers of households will grow by 2030 . Additionally, following current trends, an increasing size of new dwellings is projected until 2030. The total increase of the living area accounts approx. $29 \%$ between 2004 and 2030 and an increase of average living area from $88 \mathrm{~m}^{2}$ up to $97 \mathrm{~m}^{2}$ per dwelling in 2030 is projected. Between the countries different trends are apparent. Whereas the average living area in the Baltic States as well as in Poland are projected to increase approx. $25 \%$, in western European countries and Scandinavia the increase amounts to only 5 to $7 \%$.

In order to define and model the technical and economical characteristics two typical residential buildings have been derived as typical average values from empirical studies from the Wuppertal Institute $(2000,2001)$ and IWU (2005). They represent the bulk of dwellings all about Europe. The exact dimensions of the buildings are given in Table 2 .

Table 2: $\quad$ Average surface components of residential building types

\begin{tabular}{|l|c|c|c|c|c|c|}
\hline & Dwelling & Ceilling & \multicolumn{4}{|c|}{ Standard component surfaces $\left(\mathrm{m}^{2}\right)$} \\
\hline Building type & Space $\left(\mathrm{m}^{2}\right)$ & Height $(\mathrm{m})$ & Roof & Facade & Floor & Windows E/W \\
\hline Single/two family house & 120 & 2.5 & 90 & 166 & 63 & 29 \\
Large apartment house & 1457 & 2.5 & 354 & 1189 & 354 & 380 \\
\hline
\end{tabular}

Source: Own calculations based on Wuppertal Institute 2000, 2001; IWU 2005

\section{Thermal quality of residential buildings}

The thermal quality of a building defines its energy consumption. It mainly depends on the climatic conditions represented by the respective climate zone and heating degree days and the U-values of its surface components. Other aspects, like regional construction characteristics or energy demand for cooling, which depends on further factors, have not been taken into account in our model.

\section{Climate zones}

The most important indicator for the climate zones are heating degree days ${ }^{5}$ and this value describes the typical energy useful demand to heat buildings. Therefore, the building stock of each country is assigned to one of three climate zones: Cold, Moderate and Warm and defined by Eurostat (2006). The breakdown between these climate zones is listed below:

- Cold, above 4,200 heating degree days ${ }^{6}$ : Estonia, Finland, Iceland, Latvia, Norway and Sweden;

- Moderate, between 2,200 and 4,200 heating degree days: Austria, Belgium, Croatia, Czech Republic, Denmark, France, Germany, Hungary, Ireland, Liechtenstein, Lithuania, Luxemburg, the Netherlands, Poland, Romania, Slovakia, Slovenia and United Kingdom;

- Warm, below 2,200 heating degree days: Bulgaria, Cyprus, Greece, Italy, Malta, Portugal, Spain 7

In total about three-quarter of single family buildings and nearly two-third of multi family buildings exist in the moderate climate zone. 19 respectively $33 \%$ of single and multi family buildings are located in the warm climate zone and only $5 \%$ of single and multi family buildings belong to the cold climate zone.

\section{Energetic Standard of residential buildings}

The energetic standard (U-values) of the existing building stock have been estimated regarding the age classes: built before 1975 not refurbished and already refurbished buildings and buildings built between 1976 and 2004. Future buildings as well as refurbishments are characterized by their respective insulation standard:

- Building code 1 is comparable to currently best available standard;

- Building code 2 is a more advanced standard. It is assumed that the European Performance of Buildings Directive (EPBD) will promote the wide spread adoption of this standard in the EU;

- Building code 3 refers to low energy houses;

- Building code 4 is equivalent to passive houses.

\footnotetext{
${ }^{5}$ Heating degree days are quantitative indices and result from national temperature observations. Over one year (typically) the differences between each day's daily temperature and $18^{\circ} \mathrm{C}$ (or another reference temperature) are added. Above a temperature of $18^{\circ} \mathrm{C}$, it is assumed not to need any heating (the current indoor temperature will be higher due to insulation of the building).

${ }^{6}$ Long-term average (1980-2004)

${ }^{7}$ In this climate zone energy needs for cooling play a significant role. They are not accounted for in the current version of our model.
} 
Table 3 gives an overview of the respective U-values of the building components for the different standards and climate zones.

Table 3: $\quad$ Energetic standard of building components by climate zone and construction period of building

\begin{tabular}{|c|c|c|c|c|c|c|c|c|c|c|}
\hline \multirow{2}{*}{$\begin{array}{l}\text { U-values } \\
\text { in } \mathrm{Wm}^{2} \mathrm{~K}\end{array}$} & \multicolumn{2}{|c|}{ Before 1975} & \multirow{2}{*}{$\begin{array}{c}1976- \\
2004 \\
\end{array}$} & \multicolumn{3}{|c|}{ Refurbished (by standard) } & \multicolumn{4}{|c|}{ New (by standard) } \\
\hline & Not ref. & Alr. Ref & & 1 & 2 & 3 & 1 & 2 & 3 & 4 \\
\hline \multicolumn{11}{|c|}{ Cold Climate Zone } \\
\hline Façade & 0.50 & 0.30 & 0.25 & 0.18 & 0.17 & 0.15 & 0.18 & 0.17 & 0.15 & 0.10 \\
\hline Roof & 0.50 & 0.20 & 0.18 & 0.15 & 0.13 & 0.11 & 0.15 & 0.13 & 0.11 & 0.10 \\
\hline Floor & 0.50 & 0.20 & 0.19 & 0.18 & 0.17 & 0.15 & 0.18 & 0.17 & 0.15 & 0.10 \\
\hline Windows & 3.00 & 1.60 & 1.60 & 1.42 & 1.33 & 1.03 & 1.42 & 1.33 & 1.03 & 0.78 \\
\hline \multicolumn{11}{|c|}{ Moderate Climate Zone } \\
\hline Façade & 1.50 & 1.00 & 0.75 & 0.41 & 0.38 & 0.20 & 0.41 & 0.38 & 0.20 & 0.10 \\
\hline Roof & 1.50 & 0.50 & 0.45 & 0.25 & 0.23 & 0.16 & 0.25 & 0.23 & 0.16 & 0.10 \\
\hline Floor & 1.20 & 0.80 & 0.65 & 0.44 & 0.41 & 0.28 & 0.44 & 0.41 & 0.28 & 0.10 \\
\hline Windows & 3.50 & 2.00 & 2.75 & 1.84 & 1.68 & 1.30 & 1.84 & 1.68 & 1.30 & 0.78 \\
\hline \multicolumn{11}{|c|}{ Warm Climate Zone } \\
\hline Façade & 1.97 & 1.40 & 0.90 & 0.59 & 0.48 & 0.25 & 0.60 & 0.48 & 0.25 & 0.10 \\
\hline Roof & 2.46 & 1.00 & 0.65 & 0.50 & 0.43 & 0.30 & 0.50 & 0.43 & 0.30 & 0.10 \\
\hline Floor & 2.50 & 1.00 & 0.68 & 0.55 & 0.48 & 0.33 & 0.55 & 0.48 & 0.33 & 0.30 \\
\hline Windows & 4.70 & 3.50 & 3.85 & 3.04 & 2.71 & 1.26 & 3.04 & 2.71 & 1.26 & 0.78 \\
\hline
\end{tabular}

Source: Own calculations based on EURIMA, Ecofys (2005b); WI (2000); IWU (1994); ISIS

From the energetic standards presented in Table 3 we calculate the country specific energy demand for space heating per $\mathrm{m}^{2}$ for each building type, as given in Figure 1. The energy demand for heating is calculated using a static calculation model comparable to the Swiss norm SIA 380 (2009). For this calculation typical energetic characteristics, the specific geometry and size of the building types are taken into account. For the orientation of the building and its windows the shading from trees and neighbour buildings as well as the internal gains from inhabitants and appliances typical values are used. In this context a full compliance to the respective standard is assumed. The fact that not all refurbishments or new buildings meet the standards can be taken into account for in the definition of scenarios.

Figure 1: $\quad$ Average specific energy consumption of single family buildings according to their refurbishment standard and climate Zone

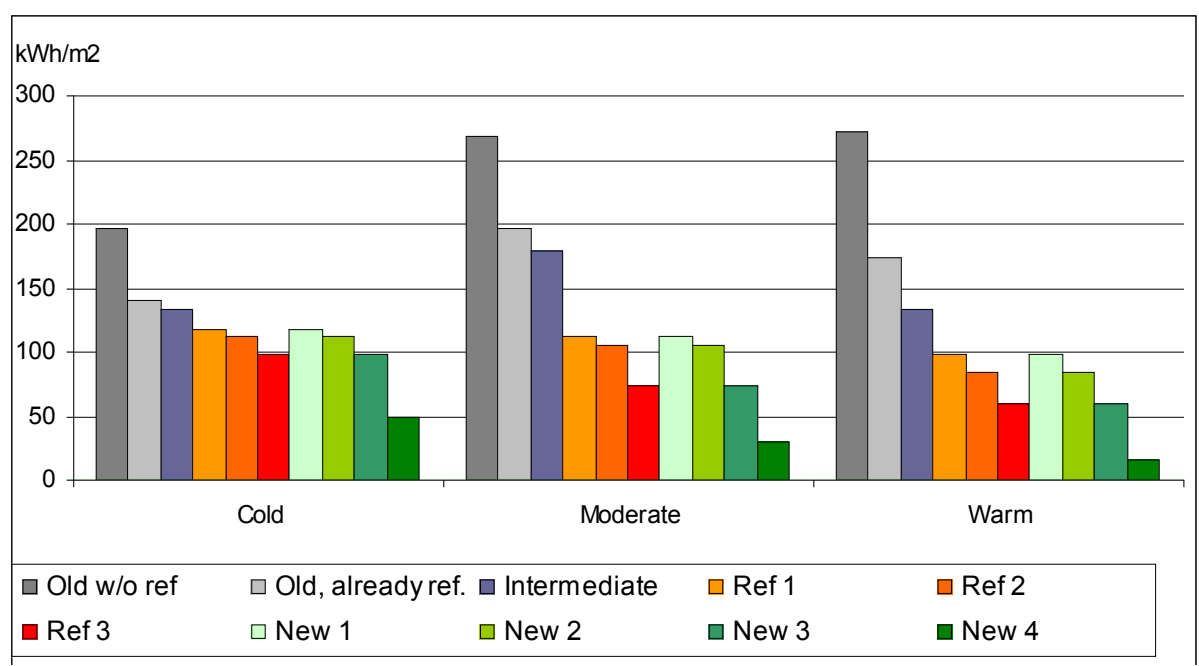

Source: Own calculations based on a static thermodynamic simulation of typical buildings according to SIA 380 and based on climate specific heating degree days (see above), energetic standards of building components as given in Table 3 and the building geometry as given in Table 2 . 
In order to reflect consumer habits, which differ from country to country and to improve the fitting with energy statistics the resulting values have been calibrated for all countries showing significant deviations by using data from Kemna et al (2007), Odyssee and the DG TREN (2006) baseline scenario.

\section{Technology costs for the improvement of the building shells}

Refurbishment measures are carried out not only to save energy and emissions they also depend on the costeffectiveness.

Table 4: Costs for building shell improvement, per refurbishment standard and climate zone in Euro/m $\mathbf{m}^{2}$

\begin{tabular}{|c|c|c|c|c|c|c|c|c|c|}
\hline \multirow{2}{*}{$\begin{array}{l}\text { Facade } \\
\text { Improvement }\end{array}$} & \multicolumn{3}{|c|}{ Cold } & \multicolumn{3}{|c|}{ Moderate } & \multicolumn{3}{|c|}{ Warm } \\
\hline & Ref 1 & Ref 2 & Ref 3 & Ref 1 & Ref 2 & Ref 3 & $\operatorname{Ref} 1$ & Ref 2 & Ref 3 \\
\hline U-value before & 0.5 & 0.5 & 0.5 & 1.5 & 1.5 & 1.5 & 1.97 & 1.97 & 1.97 \\
\hline U-value after & 0.18 & 0.17 & 0.15 & 0.41 & 0.38 & 0.2 & 0.59 & 0.48 & 0.25 \\
\hline Labour costs & 66 & 66 & 66 & 50.6 & 50.6 & 50.6 & 30.4 & 30.4 & 30.4 \\
\hline Material costs & 88.88 & 92.93 & 99 & 36.9 & 38.29 & 49.4 & 31.92 & 35.34 & 45.6 \\
\hline Total & 154.88 & 158.93 & 165 & 87.5 & 88.89 & 100 & 62.32 & 65.74 & 76 \\
\hline Add. costs vs. Std. 1 & \multicolumn{3}{|c|}{ Cold } & \multicolumn{3}{|c|}{ Moderate } & \multicolumn{3}{|c|}{ Warm } \\
\hline Building code & New2 & New3 & New4 & New2 & New3 & New4 & New2 & New3 & New4 \\
\hline U-value after & 0.17 & 0.15 & 0.1 & 0.38 & 0.2 & 0.1 & 0.48 & 0.25 & 0.1 \\
\hline Add. Costs & 5.57 & 13.92 & 41.07 & 2.78 & 25.05 & 60.81 & 5.57 & 22.27 & 55.67 \\
\hline Roof & \multicolumn{3}{|c|}{ Cold } & \multicolumn{3}{|c|}{ Moderate } & \multicolumn{3}{|c|}{ Warm } \\
\hline Improvement & Ref 1 & Ref 2 & Ref 3 & Ref 1 & Ref 2 & Ref 3 & $\operatorname{Ref} 1$ & Ref 2 & Ref 3 \\
\hline U-value before & 0.5 & 0.5 & 0.5 & 1.5 & 1.5 & 1.5 & 2.46 & 2.46 & 2.46 \\
\hline U-value after & 0.15 & 0.13 & 0.11 & 0.25 & 0.23 & 0.2 & 0.5 & 0.43 & 0.3 \\
\hline Labour costs & 37.81 & 39.11 & 44.94 & 20.55 & 22.26 & 24.43 & 13.15 & 13.61 & 15.64 \\
\hline Material costs & 18.92 & 19.57 & 22.31 & 10.28 & 10.63 & 12.12 & 6.58 & 6.81 & 7.76 \\
\hline Total & 56.73 & 58.68 & 67.25 & 30.83 & 31.89 & 36.55 & 19.73 & 20.41 & 23.39 \\
\hline Add. costs vs. Std. 1 & \multicolumn{3}{|c|}{ Cold } & \multicolumn{3}{|c|}{ Moderate } & \multicolumn{3}{|c|}{ Warm } \\
\hline Building code & New2 & New3 & New4 & New2 & New3 & New4 & New2 & New3 & New4 \\
\hline U-value after & 0.13 & 0.11 & 0.1 & 0.23 & 0.2 & 0.1 & 0.5 & 0.43 & 0.1 \\
\hline Add. Costs & 1.18 & 4.31 & 10.03 & 0.48 & 4.08 & 11.55 & 0.71 & 3.67 & 10.03 \\
\hline Floor & \multicolumn{3}{|c|}{ Cold } & \multicolumn{3}{|c|}{ Moderate } & \multicolumn{3}{|c|}{ Warm } \\
\hline Improvement & Ref 1 & Ref 2 & Ref 3 & Ref 1 & Ref 2 & Ref 3 & Ref 1 & Ref 2 & Ref 3 \\
\hline U-value before & 0.5 & 0.5 & 0.5 & 1.2 & 1.2 & 1.2 & 2.46 & 2.46 & 2.46 \\
\hline U-value after & 0.18 & 0.17 & 0.15 & 0.44 & 0.41 & 0.28 & 0.5 & 0.43 & 0.3 \\
\hline Labour costs & 21.78 & 21.78 & 21.78 & 13.8 & 13.8 & 13.8 & 10.03 & 10.03 & 10.03 \\
\hline Material costs & 29.33 & 30.67 & 32.67 & 15.27 & 16.06 & 19.2 & 6.58 & 6.81 & 7.76 \\
\hline Total & 51.11 & 52.45 & 54.45 & 29.07 & 29.86 & 33 & 20.57 & 21.69 & 25.08 \\
\hline Add. costs vs. Std. 1 & \multicolumn{3}{|c|}{ Cold } & \multicolumn{3}{|c|}{ Moderate } & \multicolumn{3}{|c|}{ Warm } \\
\hline Building code & New2 & New3 & New4 & New2 & New3 & New4 & New2 & New3 & New4 \\
\hline U-value after & 0.13 & 0.11 & 0.1 & 0.23 & 0.2 & 0.1 & 0.5 & 0.43 & 0.1 \\
\hline Add. Costs & 1.46 & 3.64 & 4.82 & 0.72 & 3.63 & 20.92 & 0.72 & 2.91 & 15.27 \\
\hline Windows & \multicolumn{3}{|c|}{ Cold } & \multicolumn{3}{|c|}{ Moderate } & & Warm & \\
\hline Improved & Ref 1 & Ref 2 & Ref 3 & Ref 1 & Ref 2 & Ref 3 & Ref 1 & Ref 2 & Ref 3 \\
\hline U-value before & 3 & 3 & 3 & 3.5 & 3.5 & 3.5 & 4.7 & 4.7 & 4.7 \\
\hline U-value after & 1.42 & 1.33 & 1.03 & 1.84 & 1.68 & 1.3 & 3.04 & 2.71 & 1.26 \\
\hline Labour costs & 262 & 262 & 262 & 176 & 176 & 176 & 127 & 127 & 127 \\
\hline Material costs & 304 & 334 & 364 & 237 & 259 & 280 & 162 & 172 & 182 \\
\hline Total & 566 & 596 & 626 & 413 & 435 & 456 & 289 & 299 & 309 \\
\hline Add. costs vs. Std. 1 & & Cold & & & Moderat & & & Warm & \\
\hline Building code & New2 & New3 & New4 & New2 & New3 & New4 & New2 & New3 & New4 \\
\hline U-value after & - & - & 0.78 & - & - & 0.78 & - & - & 0.78 \\
\hline Labour costs & - & - & 262 & - & - & 176 & - & - & 127 \\
\hline Material costs & - & - & 393 & - & - & 302 & - & - & 192 \\
\hline Total & - & - & 655 & - & - & 478 & - & - & 319 \\
\hline
\end{tabular}

Source: Own calculations based on IWU (2006) 
For three different types of refurbishment and four types of new buildings material and labour costs have been derived from technological analyses from IWU (2006), Ecofys (2005b) and Jakob et al. (2002). The following table 4 gives a detailed overview on the current specific energy efficiency investment for different parts of the building shell and different standards.

To project the costs into country-specific values, two indices are generated, material and labour cost index. The labour costs have been from Eurostat data about the salaries of workers in the construction sector in 2007 and projected with the projected GDP-development of each country taken from the EU Baseline Scenario (DG TREN 2006). In order to calculate country specific material costs for insulation and construction of buildings, a BBR (2005) report provides a current state of the art about the differences of material and insulation costs for Germany as well as for central and east European countries. These values are taken to define five country groups according to their relative material costs: For the middle and western European countries in the moderate climate zone German material cost level is assumed, while material costs are 10\% higher in Scandinavian countries, about $10 \%$ lower in the New Member States from 2005, 5\% lower in Greece, Spain, Portugal and Slovenia and 12\% lower in Bulgaria and Romania as well as in Croatia.

Jakob et al. (2002) show that building materials (e.g. windows) have become cheaper over the last decades in spite of significantly increasing energetic quality. They conclude that this effect will be relevant also for the future. Based on these findings we have estimated future cost reductions due to larger sales of advanced insulation components, improved skills and higher productivity of workers ${ }^{8}$ etc. for every refurbishment measure. On average these lead to decreasing costs by about $15 \%$ over the period from 2004 to 2030 .

\section{Scenario Analysis}

In order to be able to estimate the energy savings potentials and GHG emission reduction potentials of policies and measures regarding the building shell of residential buildings we have carried out a scenario analysis. The scenarios are based on 2004 which is the base year of our analysis due to the available data on building stock and last until 2030. Basic trends such as population development and future GDP of the analysed countries have been derived from the DG TREN (2006) baseline scenario. Regarding demographic trends such as declining household sizes and increased size of new dwellings a by country projection of the residential living space has been developed (see above).

The core strategies analysed in the scenarios are:

- $\quad$ Tightened building standards for new and renovated buildings. In different scenarios it has been assumed that this market conversion will be achieved by a mix of regulation (building codes) and fiscal and other incentives.

- Improved compliance to the standards, achieved by better control, increased awareness of building quality, information of investors and improved training of professionals in the building sector.

- Most important - increased refurbishment rates of the building shells of existing buildings. These need among others significant financial incentive structures in order to mobilise the necessary investment.

- And increased share of energetic improvements aligned with the renovation of buildings.

In order to reflect different social and economic backgrounds of the countries as well as their climatic conditions, four socio-economic country groups have been defined. These regions have been chosen because countries are linked to each other within the groups due to same climate zone and political background. Hence, it is assumed that these groups show comparable market situations with regards to the strategies analysed:

- Group North-Western Europe (NW) consists of the Middle and Western European countries Austria, Belgium, Germany, France, Ireland, Liechtenstein, Luxemburg, the Netherlands and United Kingdom and the Scandinavian countries (Sweden, Norway, Denmark, Iceland) and Finland. It is supposed that $1.2 \%$ of the building stock will be refurbished autonomously. This value will slightly increase by 2030 . New building codes are reflecting the current standards (standard 1). In many countries of the group these building codes have already been introduced or introduction is planned.

- Southern Europe (South) consists of following countries: Greece, Spain, Italy, Portugal and Slovenia, as one of the New Member States of 2005, acceding the European Union. In contrast to North-Western Europe the autonomous refurbishment is estimated lower at $0.9 \%$ per year and the new building codes are assumed to be less strict.

\footnotetext{
${ }^{8}$ An increasing productivity of workers does not automatically lead to lower costs. However, according to past trends we assume here that much higher volumes of refurbishment will make lower prices feasible, due to learning and increasing competition.
} 
- The New Member States of the European Union (Cyprus, Czech Republic, Estonia, Lithuania, Latvia, Malta, Poland and Slovakia, which acceded in 2005) belong to the group New Member States 2005 (NMS05), except Slovenia. Approximately $0.7 \%$ of the building stock will be refurbished autonomously in this group and building codes for new buildings will be comparable to those in Southern Europe.

- The most recently acceded Member States Bulgaria and Romania and Croatia, as candidate country to the European Union, belong to the group New Member States 2007 (NMS07). The upper limit of retrofit measures of the building stock is only approx. $0.5 \%$ per year, but will increase until 2030 to a level of $0.9 \%$ as well as the building codes for new buildings which will be strengthened to Southern European standards.

Based on these assumptions about the current and future trends in the residential buildings construction sectors of the MS an Autonomous Scenario as a baseline has been developed.

\section{Autonomous Scenario}

The following Figure 2 gives an overview of current refurbishment rates and possible future developments by socioeconomic regions. Current refurbishment rates of buildings are significantly below the rates that would be necessary to cope with regular reinvestment due to lifetimes of components, which are typically between 25 years for windows and 30 to 50 years for the façade, floors and the roof. In fact, current refurbishment rates are between $1.2 \%$ in NorthWestern Europe and $0.5 \%$ in the recently acceded countries Romania and Bulgaria as well as for Croatia. Of these refurbishments only a fraction of 40 to $60 \%$ is also renovated energetically, means refurbished as Ref 2 or 3 or newly built up as New 2, New 3 or New 4.

Thus, the Autonomous scenario assumes that refurbishments will be carried out with standard 1 only (Ref 1). From 2010, higher standards (Ref 2 \& 3) will be introduced. By 2030, the rates of the more ambitious refurbishment rates will be increasing, while Ref 1 decreases up to zero \% market share. It is assumed that the Autonomous Scenario will see increasing rates of renovation out of more or less constant low frozen total renovation rates.

Figure 2: $\quad$ Rates of refurbishment rate per year, Autonomous Scenario

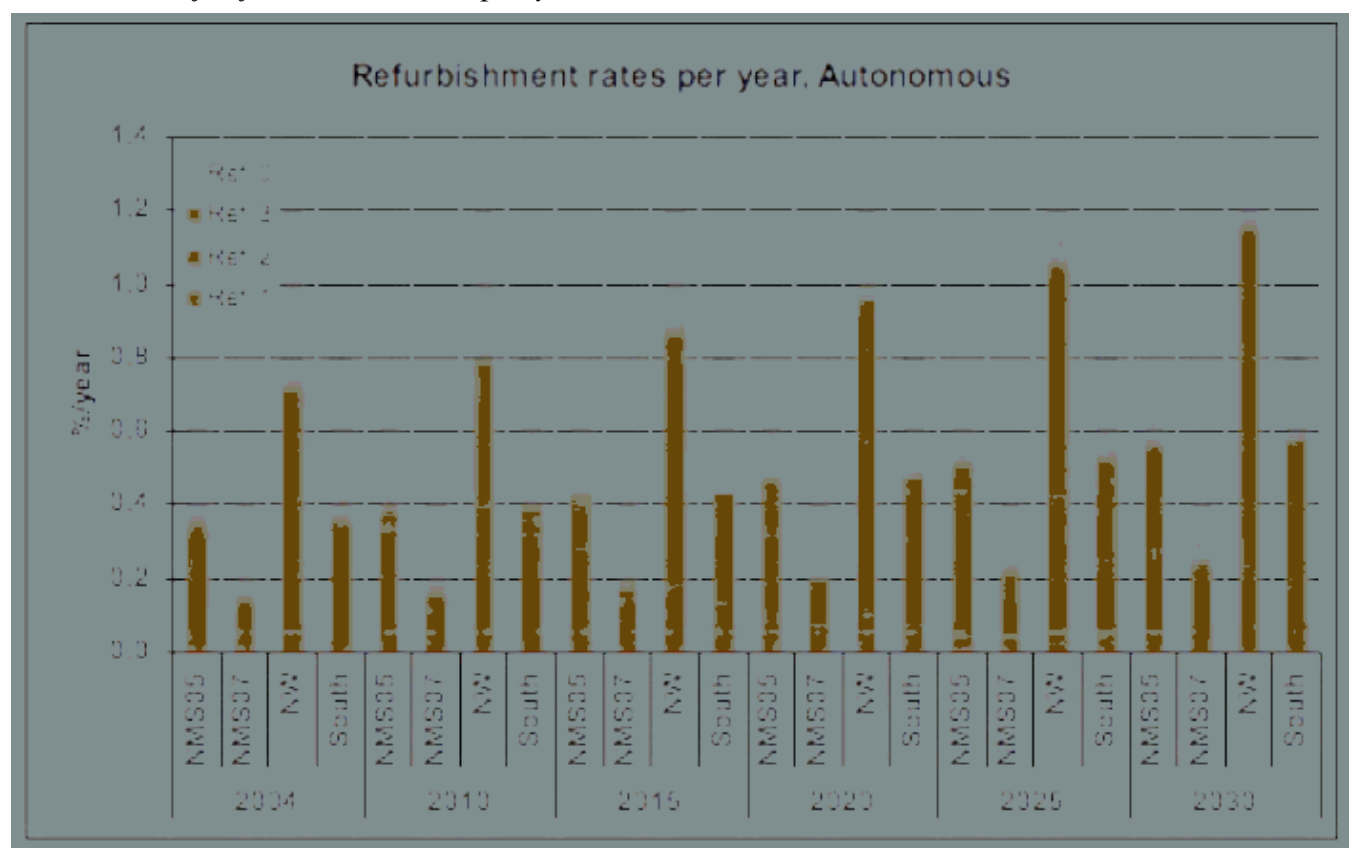

Source: Own calculations based on ISI et al. (2009) (2004: base year of calculations)

New buildings will be built mainly with the current energetic standards for new buildings. From 2010 the share of stricter building codes increases as given in 


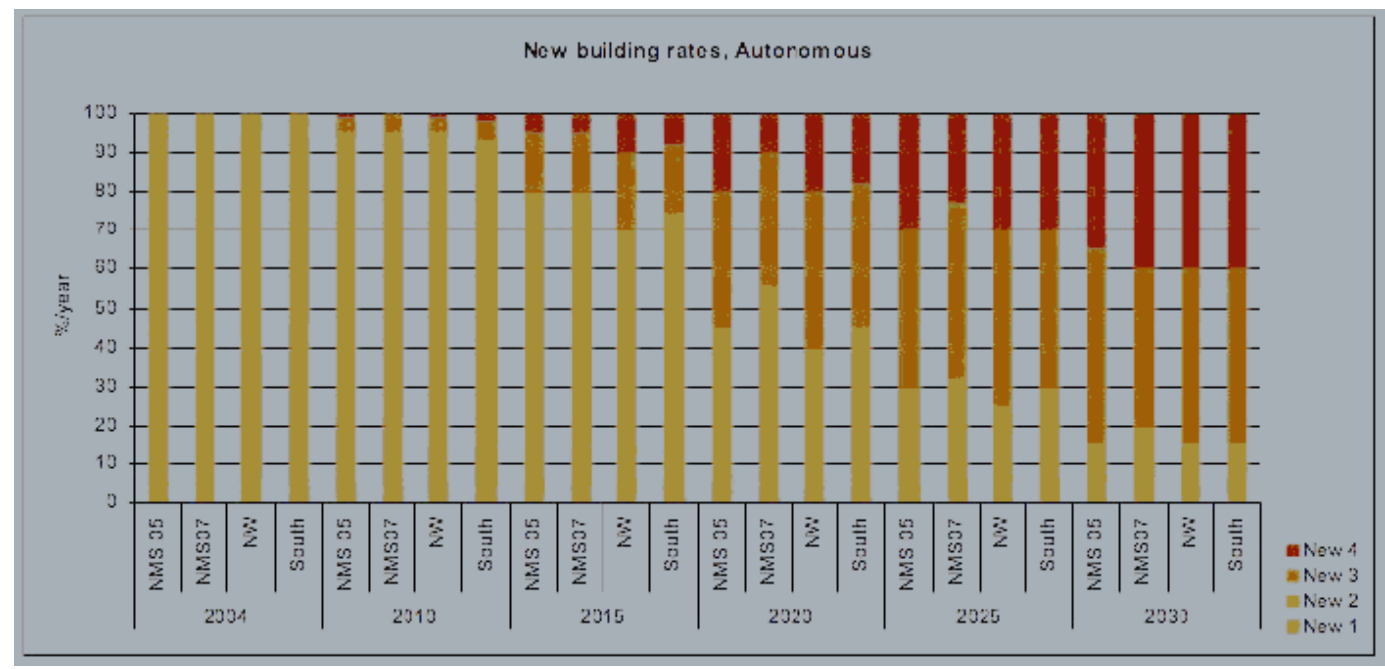

Source: Own calculations

Jakob and Madlener (2004) have already identified that many barriers still exist, in order to prevent a more effective diffusion of more suitable energy efficiency technologies. One important barrier is the fact that not every refurbishment is done with appropriate quality. Expert opinions ${ }^{9}$ about the compliance to building codes, relating to refurbishment measures as well as for new buildings have been used to model this effect. According to Warren (2008) and Hjorth (2008), between 50\% and 65\% of all new homes fail to meet basic energy standards and the specific energy consumption per $\mathrm{m}^{2}$ thus is higher than in buildings meeting the standard. Separate non-compliance factors of refurbished and new buildings were estimated and are taken into account by defining the specific energy consumption per $\mathrm{m}^{2}$ for all four scenarios.

\section{Scenario Technical Potential}

The technical potential scenario has been developed to explore the potentials for energy savings in the residential building sector. It assumes a speeding up of the refurbishment rates up to a level assumed to mark the feasible maximum level together with $100 \%$ energetic renovation rates at high standards. Thus, a politically supported increase of renovation rates up to the maximum feasible level at about 4\% per year is supposed, cp. Figure 4.

Figure 4: $\quad$ Rates of new building codes per year, Technical Potential Scenario

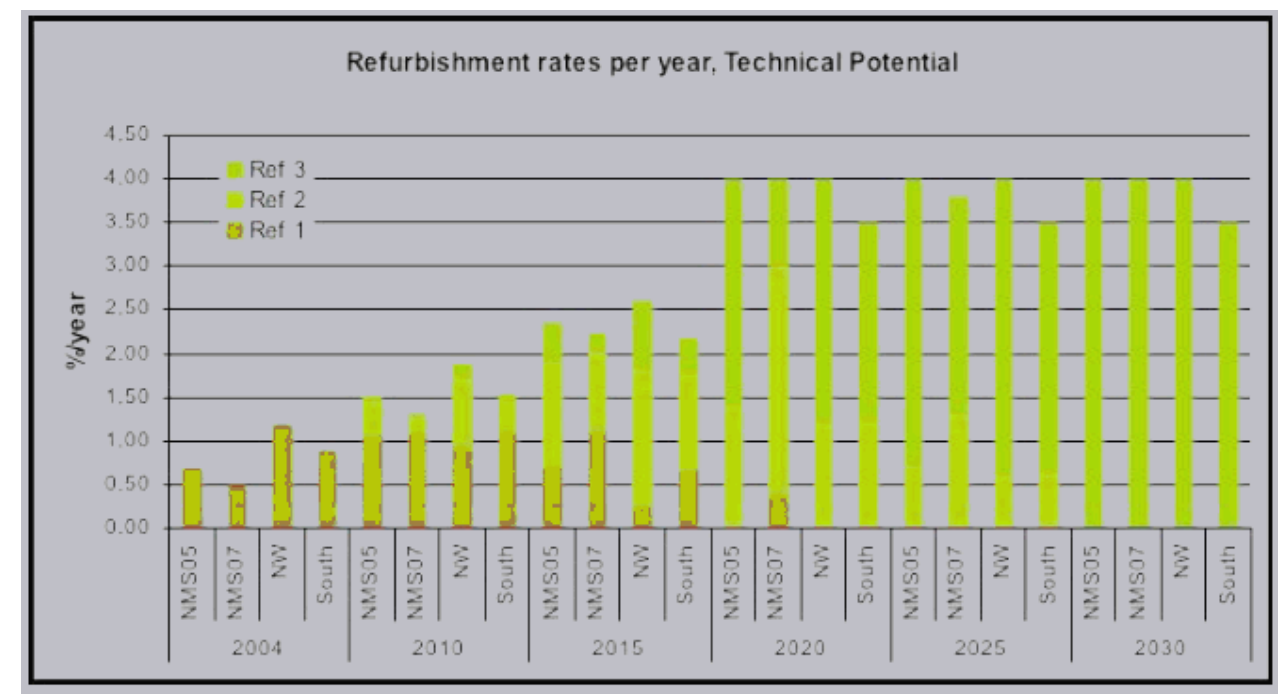

Source: Own calculations

With a strong political promotion of the current most efficient building standard, it is assumed that in 2010 already $20 \%$ of the new buildings could achieve the passive house standard (New 4) in North-Western Europe, Southern

\footnotetext{
${ }^{9}$ See the results of a workshop about energy efficiency and their enhanced compliance organised by the International Energy Agency (IEA) February 2008 in Paris.
} 
Europe and in the New Member States which acceded to the EU in $2005^{10}$. In North-Western Europe the market share of this standard will already reach 100\% in 2020, whereas in New Member States 2007 and Croatia will reach a market share of about $85 \%$, cp. Figure 5. By 2025 almost every region has reached $100 \%$ passive houses in the market for new buildings, except the NMS07.

Figure 5: $\quad$ Rates of new building codes per year, Technical Potential Scenario

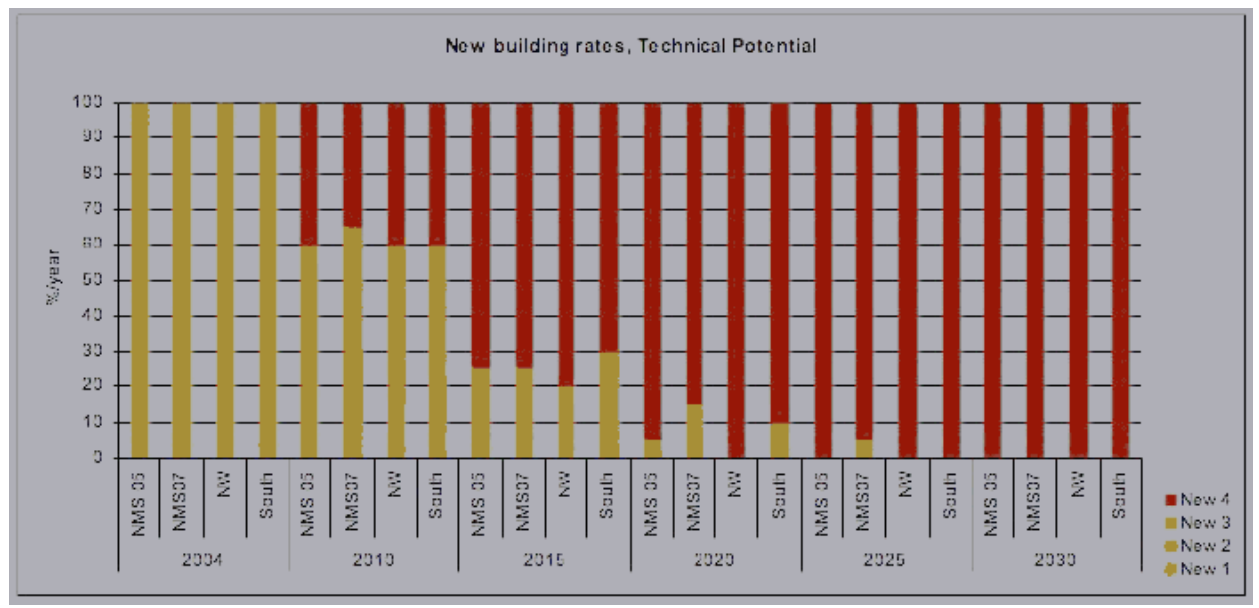

Source: Own calculations

\section{Results}

Resulting from the modelling of the before mentioned strategies with regards to the improvement of the building shell of residential buildings in the EU27 residential building stock, its future additions, the assumptions regarding the amount and effectiveness of refurbishments the following results have been derived for four scenarios:

- $\quad$ Autonomous Scenario (AS) (as described above);

- Low Policy Intensity (LPI); Here it is assumed that policies with a low intensity will be introduced and thus only a part of the additional potential refurbishments will be done and also the standards of the buildings will be improved slowly.

- High Policy Intensity (HPI); In this scenario a more active policy is assumed that is targeted at exploiting a significant share of the technical options.

- Technical Potential (TP) (as described above)

Figures 6 and 7 show the total numbers of the energy savings achievable by thermal improvement of the building shell of existing buildings as a combination of higher standards, better compliance and increased rates of energetic refurbishments and of the savings achievable by improved standards and compliance for new residential buildings.

\footnotetext{
${ }^{10}$ This assumption of our Technical Potential scenario is no longer realistic as a market share of $20 \%$ for passive houses in new buildings has been achieved only in few regions. However, in theory it is still possible that in the technical scenario a $100 \%$ share of passive houses would be implemented by 2015 which then would roughly compensate the current delay. Overall we assume that the TP-Scenario still is a relevant indication for the technical potential.
} 
Figure 6: Energy Efficiency potential from the refurbishment of the building shell of existing buildings by scenario

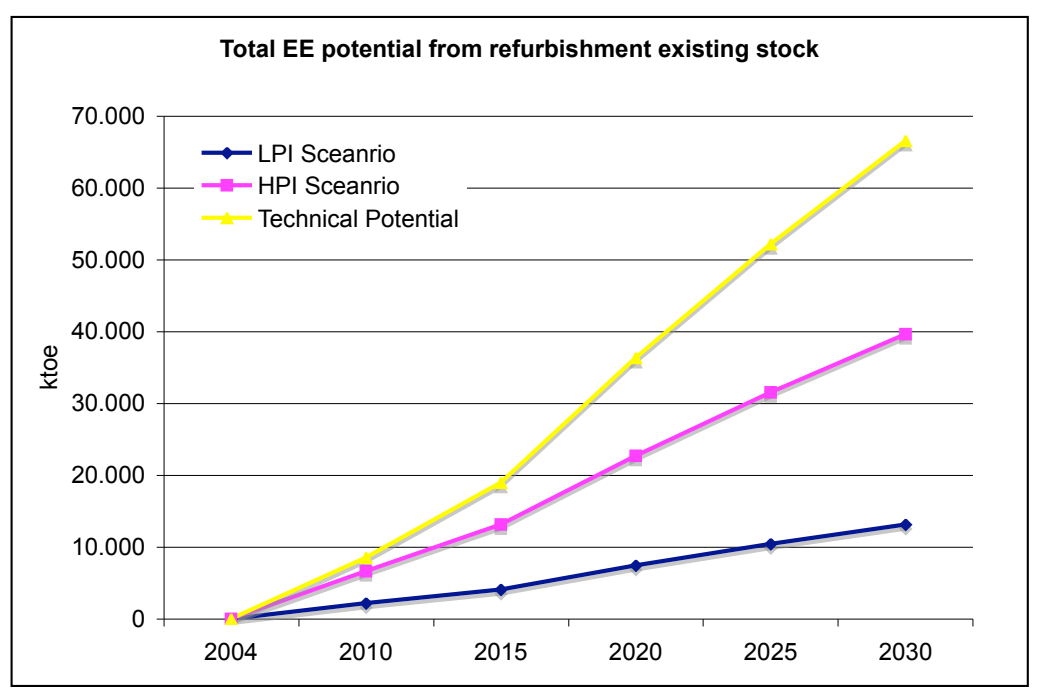

Source: Own calculations, Note: the calculation only includes energy needs for space heating. The efficiency of the heating system and further needs for air conditioning are not taken into account.

Figure 7: $\quad$ Energy Efficiency potential from improved insulation of new buildings by scenario

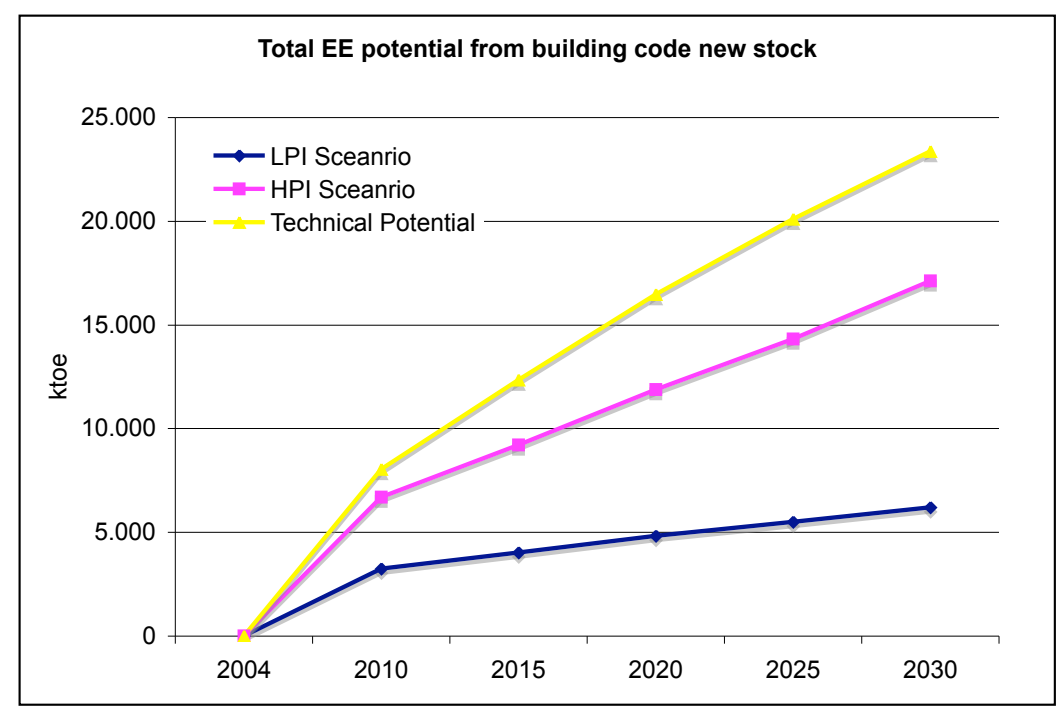

Source: Own calculations

These savings are shown against the autonomous trend (scenario Autonomous). It is thus clear that refurbishing of existing buildings has the higher quantitative relevance. By 2030 more than three thirds of the savings can be achieved here, compared to the savings by improved standards of new buildings. It is essential to keep in mind that the figures show the saving potentials for each scenario versus the Autonomous Scenario. The Autonomous Scenario includes already energy efficiency improvements and therefore the saving potentials can be seen as additional savings.

The following figure 8 shows the relative size of the technical potential. The useful energy demand of existing buildings will decrease already in the autonomous scenario, due to autonomous energetic improvements and partly demolishing of existing buildings. However the technical potential available would allow to reduce the useful energy demand to about two third of the current level by 2030 . 
Figure 8: $\quad$ Technical savings potential for existing buildings (built before 2004) by region

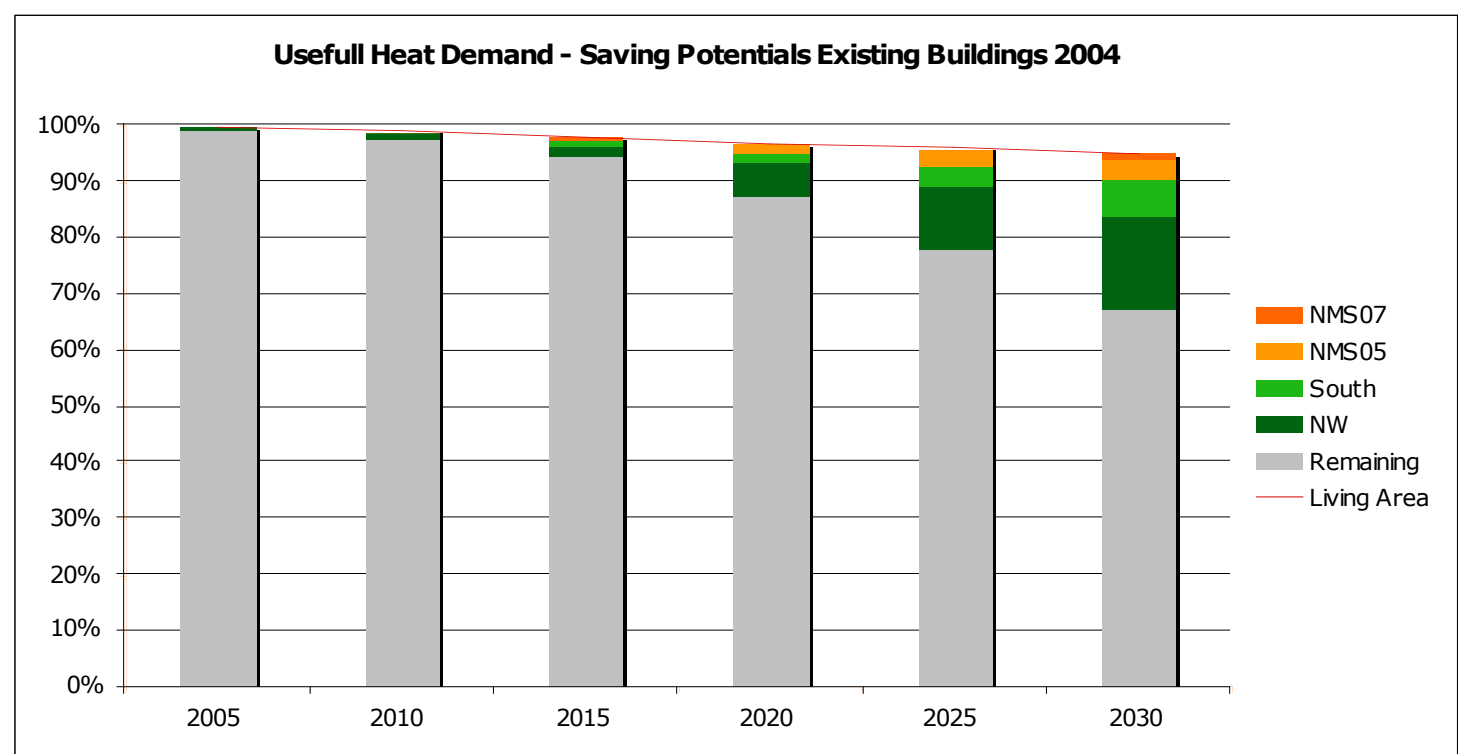

Source: Own calculations (please notice the total reduction of living area in existing buildings due to demolishing and re-use of existing buildings)

The break up by regions shows that the bulk of the potential lies in the NW region, which consists of "old" EU member states from the north and west of Europe. Figure 9 splits the potentials by country. It makes clear that in Germany, France and the UK almost $50 \%$ of the potential are located. The next three countries of high relevance in other climatic and/or socio-economic regions are Italy, Poland and Spain. They add up to another fourth of the total potential.

Figure 9: $\quad$ Share of Saving Potential by country 2020

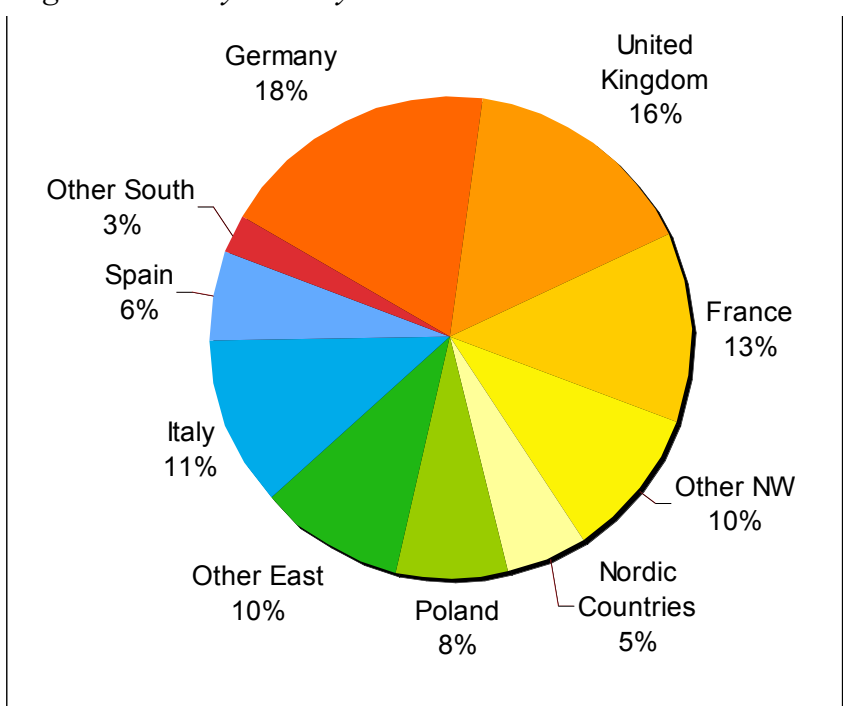

Source: Own calculations

Figure 10 summarizes the economic results of the autonomous and the technical potential scenario. Achieving the huge potential of refurbishing over $80 \%$ of all existing residential buildings needs high investments, which amount to more than 250 billion Euro per year if the technical potential will be realized.

- This amounts to about $1 \%$ of GDP by 2010 and almost $2 \%$ of GDP by 2020 which are to be invested for refurbishing up to $4 \%$ of all existing buildings per year vs. the value of $0.4 \%$ of GDP which can be envisaged for the autonomous trend.

- However this investment is almost completely determined by the fact that the current and autonomous refurbishment rates of significantly less than $1 \%$ per year are to low to sustain the building stock. They thus have to be increased anyway. 
- The share of additional costs to implement improved energetic standards such as low energy and passive house components is almost marginal. It only amounts to about $0.1 \%$ of GDP in 2020 plus the additional costs for improved new buildings which are less than $0.05 \%$ of GDP. This is supported by the results of Table 4. The marginal costs for refurbishing buildings with a higher standard are very small as compared to the full costs of the measures. E.g. refurbishing outer walls in a moderate climate zone costs about $88 € / \mathrm{m}^{2}$ with standard 1 and $100 €$ or just $14 \%$ more with standard 3 .

- Further, the additional costs to implement highest standards feasible are highly economic. The total additional investment in the Technical Potential Scenario is less than 300 bln $€$ over the scenario period. The savings, however, amount to more than $1200 \mathrm{TWh}$. With average investment of less than $30 \mathrm{ct}$ per $\mathrm{kWh}$ these investment will pay back in about three years at current costs of useful heating energy ${ }^{11}$.

Figure 10: $\quad$ Investments for refurbishment (residential building shell, Technical Potential (TP) vs. Autonomous Trend $(A T))$

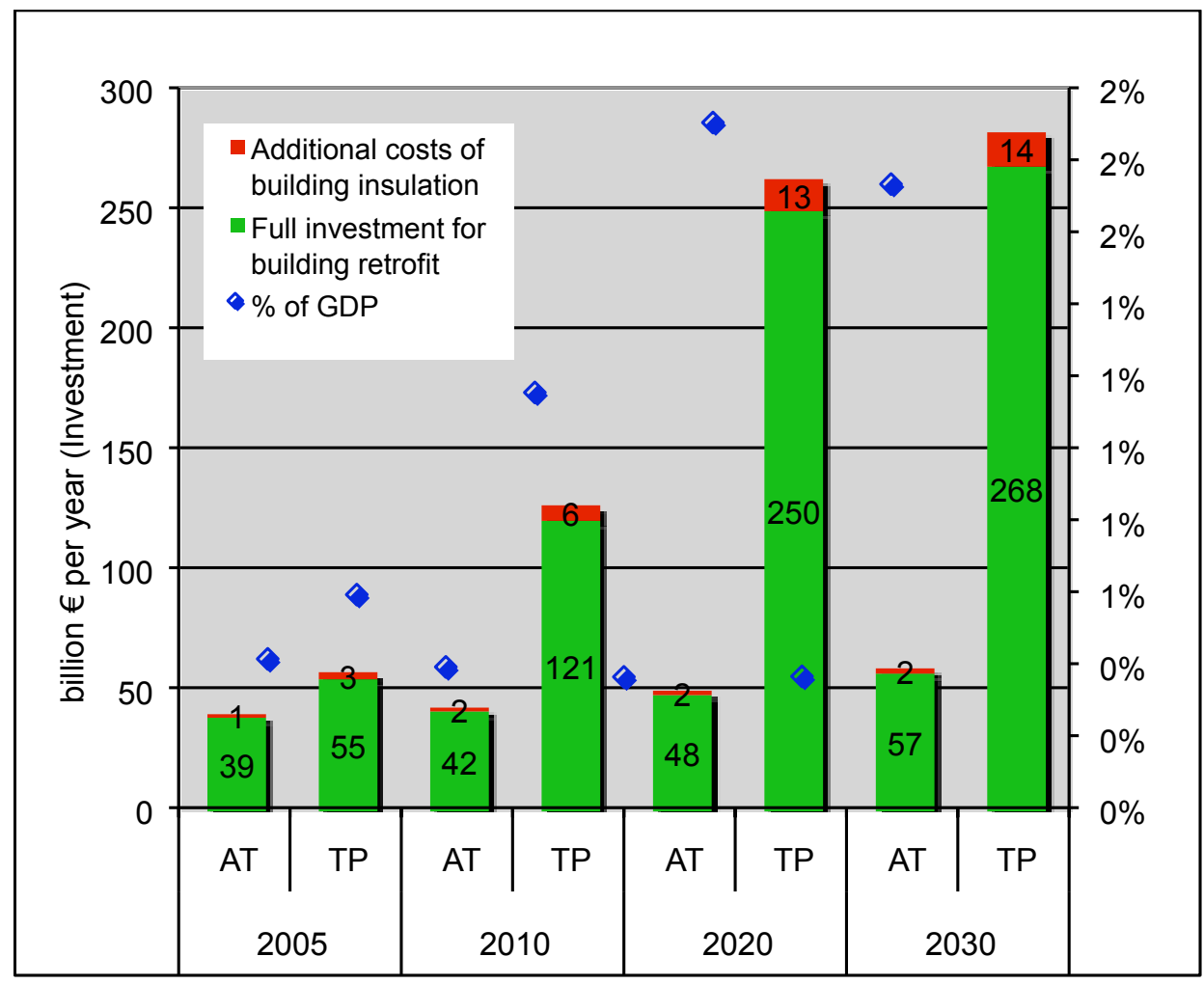

Source: Own calculations

\section{Conclusion}

This paper is based on a differentiated bottom up modelling of the energetic characteristic of the building shells of the EU residential buildings which is a core determinant of their energy use. Other factors, however, like the efficiency of the heating systems, the specific GHG emitting characteristics of the energy carriers used as well as the energy consumption due to the need for ventilation and air conditioning in warmer climates have not been incorporated into this analysis. Due to a lack of data on details of the EU building stock and its physical qualities the results contain a significant uncertainty, particularly for country benchmarks.

In spite of these limitations our results clearly show that the improvement of the building shell of existing and new residential buildings in principle offers a huge potential for energy savings which amounts to roughly about 90 Mtoe by 2030 for the EU27. This enormous potential is located by more than two third in the already existing buildings. Achieving it would need a refurbishment of these buildings over the next 20 years to the best available insulation standards.

The scenarios presented here show that achieving this potential will need a combination of higher quality energetic refurbishments which could be instrumented by a strengthening of building codes and better implementation of those into construction business, and - probably most important - a significant ramp up of refurbishment rates.

\footnotetext{
${ }^{11}$ Here not only fuel prices have to be taken into account but also the average and the other variable costs of the heating system.
} 
The fact that the Western European Countries make up more than 50\% of the saving potential, which have already altered their building codes in recent years and/or have already planned further strengthening in the future, shows that the first strategy element is already emerging. This, however, emphasises the relevance of the second, increasing of investment into refurbishing the building stock.

An accelerated refurbishment strategy clearly needs significant investment: The annual investment needed for the additional energetic improvement combined with refurbishments of all buildings is estimated here at about $0.15 \%$ of the GDP of the EU by 2020. This investment is highly economic with an estimated payback time of tree years and less. However, the overall investment for refurbishing the buildings itself is more than 10 times higher. The currently insufficient volume of reinvestment into maintenance and modernisation of residential buildings which is estimated at about 55 billion EURO per year had to be increased as a maximum by about five times in order to exploit the full potential and modernise about $80 \%$ of the residential buildings in the EU over the next 20 years. One example to achieve increasing modernisation rates are the German loan programmes for energetic refurbishments of existing buildings which have been constantly extended over the last decade. By these funds -98 mln $€$ of funds and 5.5 bln $€$ of low interest loans) in 2009 alone about $1.3 \%$ of the existing dwellings have been refurbished (KfW 2010).

This shows that the full exploitation of the energy savings potentials from energetic refurbishment needs high investments, not so much for the insulation measures themselves, but particularly because more buildings are to be renovated than expected in the autonomous scenario. That's why this strategy is linked to a significantly accelerated building modernisation strategy for the EU. To instrument the accelerated modernisation seems to be a crucial strategy which has to complement the recently completed EPBD recast. Instruments could be targeted tax rebates and other subsidy programmes for building refurbishment combined with a stepwise introduction of minimum standards and/or market based instruments such as labelling schemes etc.

\section{References}

BBR (Bundesamt für Bauwesen und Raumordnung) (2005): Bauwirtschaftliche Kooperationschancen bei der energetischen Sanierung des Wohnungsbestandes in MOE-Partnerstaaten am Beispiel der Ukraine. Project on behalf of the Federal Ministry of Transport, Building and Urban Affaires. Bonn. http://www.bbr.bund.de/

BBR (Bundesamt für Bauwesen und Raumordnung) (2006): Siedlungsentwicklung und Infrastrukturfolgekosten. Bilanzierung und Strategieentwicklung. Project on behalf of the Federal Ministry of Transport, Building and Urban Affaires. Bonn. http://www.bbr.bund.de/

Boverket, MMR (2005): Housing Statistics in the European Union 2004. National Board of Housing, Building and Planning, Sweden (Boverket) and Ministry for Regional Development of the Czech Republic (MMR). Karlskrona.

Dechent, Jens (2006): Zur Entwicklung eines Baukostenindexes. Statistisches Bundesamt, Wirtschaft und Statistik 2.2006. Wiesbaden.

DG TREN (2006): New (2005) Energy Baseline, M. Decker, Presentation to National Emission Ceilings and Policy Instruments Working Group, Meeting on 1. 2. 2006.

ECOFYS (2005a): Cost-effective Climate Protection in the Building Stock of the New EU Member States. Beyond the EU Energy Performance of Buildings Directive. European Insulation Manufacturers Association (EURIMA). Brussels, Cologne.

ECOFYS (2005b): Cost-Effective Climate Protection in the EU Building Stock. European Insulation Manufacturers Association (EURIMA). Brussels, Cologne.

Eurostat (2006): Statistische Aspekte der Energiewirtschaft 2004. Zunehmende Energieabhängigkeit der EU-25. Eurostat Abteilung Umwelt und Energie. Heft 5.2006. Luxemburg. http://epp.eurostat.ec.europa.eu

Eurostat (2007): Annual price indices for new residential buildings. http://epp.eurostat.ec.europa.eu/portal/page? pageid $=0,1136195,0 \quad 45572097 \&$ dad=portal\& schema=PO RTAL (accessed 05.07.07).

Eurostat (2007): Labour cost surveys.http://epp.eurostat.ec.europa.eu/portal/page?_pageid= 0,1136184,0_45572595\&_dad=portal\&_schema=PORTAL (accessed 27.06.07).

Euroconstruct (ed.) (1999): EUROPARC - Der Bestand an Gebäuden in (West-) Europa (Deutschland, Frankreich, Großbritannien, Italien und Spanien). Bearbeitung der deutschen Fassung und des Länderberichts Deutschland: Ifo Institut für Wirtschaftsforschung. München. 
Hjorth, Hans (2008): Another way of checking building compliancy. Swedish experience with compliance and the use of metered data. Speech at IEA"International Workshop on Meeting Energy Efficiency Goals. Enhanced Compliance, Monitoring and Evaluation. Stream 1: Buildings. 28-29.02.2008. Paris.

ISI, Enerdata, ISIS, TU Vienna, Wuppertal Institute (2009):Study on the Energy Savings Potentials in EU Member States, Candidate Countries and EEA Countries, Final Report for the European Commission DirectorateGeneral Energy and Transport EC Service Contract Number TREN/D1/239-2006/S07.66640

Itard, Laure; Frans Meijer; Evert Vrins, Harry Hoiting (2007): Building Renovation and Modernisation in Europe. State of the Art Review. OTB Research Institute for Housing and Mobility Studies. Delft University of Technology. Delft.

IWU (Institut Wohnen und Umwelt) (2006): Gebäudetypologie Bayern. Entwicklung von 11 Hausdatenblättern zu typischen Gebäuden aus dem Wohnungsgebäudebestand Bayerns. Report on behalf of Bund Naturschutz Bayern e.V. Darmstadt.

IWU (Institut für Wohnen und Umwelt) (1994): Passivhaus-Bericht Nr. 7. Fenster und Rahmendämmung im Passivhaus. Darmstadt.

Jakob M. and Madlener R. (2004): Riding Down the Experience Curve for Energy-Efficient Building Envelopes: The Swiss Case for 1970-2020, International Journal of Energy Technology and Policy (Special Issue on "Experience Curves"), 2(1-2): 153-178.

http://www.cepe.ch/download/staff/reinhard/IJETP_vol2_no1_2_jakob_madlener.pdf

Jakob M., Jochem E. and Christen K. (2002). Grenzkosten bei forcierten Energieeffizienzmaßnahmen bei Wohngebäuden, CEPE und HBT, ETH Zürich, Studie im Auftrag des Forschungsprogramms EWG des Bundesamts für Energie (BFE), September 2002. http://www.cepe.ch

Kemna, René; Martijn van Elburg; William Li; Rob van Holsteijn (2007): Eco-design of Boilers. Task 3. Report. Consumer Behaviour and Local Infrastructure. Van Holsteijn en Kemna reported for EC. Delft.

KfW (2010): Förderreport der KfW-Bankengruppe, Stand 31.12.2009, Frankfurt

Lechtenböhmer, S. et al. (2005): Target 2020: Policies and Measures to reduce Greenhouse gas emissions in the EU. A report on behalf of WWF European Policy Office. Wuppertal.

MIIR (Ministry of Infrastructure of the Italian Republic), FIHF (Federcasa Italian Housing Federation) (2007): Housing Statistics in the European Union 2005/2006. Rome.

SIA 380/1 (2009): Thermische Energie im Hochbau. http://www.energie.zh.ch/internet/bd/awel/energie/de/ Fachinfo/SIA_380-1.html

Warren, Andrew (2008): Compliance with Building Regulations. Speech at IEA"International Workshop on Meeting Energy Efficiency Goals. Enhanced Compliance, Monitoring and Evaluation. Stream 1: Buildings. 28-29.02.2008. Paris.

Wuppertal Institut (1999): Die Sanierung des Wohngebäudebestandes - Eine Chance für Klimaschutz und Arbeitsmarkt?. Endbericht im Auftrag von IG BAU und Greenpeace e.V. Wuppertal.

Wuppertal Institut (2000): Klimaschutz- und Innovationsstrategie für die Landkreise Lahn-Dill und Gießen. Wuppertal.

Wuppertal Institut, Öko-Institut (2001): Bewertung eines Ausstiegs aus der Kernenergie aus klimapolitischer und volkswirtschaftlicher Sicht mit überarbeiteter Zusammenfassung vom Januar 201. Wuppertal, Freiburg.

\section{Acknowledgements}

This paper is partly based on research conducted by the Wuppertal Institute in the framework of the Study on the Energy Savings Potentials in EU Member States, Candidate Countries and EEA Countries for the European Commission, Directorate-General Energy and Transport (EC Service Contract Number TREN/D1/2392006/S07.66640) which was carried out in cooperation with FHG-ISI, ISIS, Enerdata and TU Vienna. We would like to thank our colleagues from the research institutes and the officers from DG TREN for the useful discussion and inputs to our work as well as Thomas Hanke from the Wuppertal Institute for his contribution for systems analysis and modelling of the data. We particularly thank the reviewers from Energy Efficiency for their valuable comments, and Jacky Pett for reviewing an earlier version of the paper. 